\title{
Effect of Multi Nutrient on Sweet Orange
}

\author{
Smita R. Chaudhari. ${ }^{1}$; A. B. Gawate. ${ }^{2}$, R. S. Chaudhari ${ }^{3}$ \\ ${ }^{1}$ Ph.D Scholar, N. E. S. Science College Nanded. \\ ${ }^{2}$ Principal, Shri Sant Gadge Maharaj ACS College, Loha, Dist- Nanded \\ ${ }^{3}$ Subject Matter Specialist, Krishi Vigyan Kendra, Jalna.
}

\begin{abstract}
Sweet orange one of the most important fruit crop. The deterious effect of the nutrient stress lead to reduction in fruit yield and quality of sweet orange. The aim of this paper is to review the current knowledge to evaluate the effect of multinutrient on yield and quality attributes of sweet orange. The result of many works indicates that number of fruits per tree, weight of fruit increased with the application of balanced dose of NPK along with multi micronutrient. The quality of fruits in terms of juice, TSS, fruit girth, ascorbic acid content, reducing and nonreducing sugar increased with the application of multi micronutrient along with NPK. Whereas acidity is low in balance nutrient application in field.
\end{abstract}

Keywords: Sweet orange, multi micronutrient, NPK, yield of fruit, quality of fruit.

\section{Introduction}

The productivity of sweet orange mainly depends on adequate supply of plant nutrients seems to be a very important factor in regulating cropping and influencing the quality of sweet orange. However, our knowledge regarding fertilizer and requirement, time of fertilization, form of fertilizer, method of application etc. it still incomplete and more work is needed on these aspects. Evergreen sweet orange is nutrient loving plant and all essential elements have been known to have important role to play for proper growth and development of sweet orange. The sufficient supply of nutrient not only for development of vegetative structure and flowers but also to give regular harvest of quality fruits. Inadequate plant nutrition causes serious disorders in sweet orange and many eventually lead to decline the orchards. On the other hand, proper fertilization of sweet orange trees ensures high yield and good quality fruits year after year. Therefore constant vigilance is required to maintain an optimum nutritional level for maximum production of high quality fruits. (Bose et al., 1998).

The response of fertilization in improving the growth, yield and quality of different citrus fruits is well recognized (Ghosh, 1990; Kumar et al.1993; Ram et al., 1997 and Shukla et al., 2000). Calvert (1970) has reported that significant role of $\mathrm{N}, \mathrm{P}, \mathrm{Mg}, \mathrm{Zn}$, and $\mathrm{B}$ on growth, yield and quality of citrus fruits in India. Huchche et al. (1998) also reported that application of chemical fertilizers along with organic soil amendments increased mandarin yield in India.

\section{Effect on yield parameter of fruits}

Citrus can thrive well under a wide range of nutrient levels and it is impossible to outline a single fertilization programme that would suit all citrus growing condition. A wide variety of programme are being now used which result in high yield of good quality fruits (Bose et al., 1998).

Tariq et al., (2007) observed that application leads to more number of fruits in sweet orange and yield were increased significantly. Fruit quantity parameters like number of fruits per tree, weight of fruits per tree and productivity per hector as influenced by use of multinutrients. During two years trial (2007 \& 2008) NPK bulk recommended dose + multi micronutrient through soil showed significantly superior values of number of fruits per tree (554 \& 553), weight of fruit per tree $(132.90$ and $143.80 \mathrm{~kg}$ and productivity per hector $(36.18$ and $39.83 \mathrm{t} / \mathrm{ha}$ ) (Kazi et al., 2012). Ghosh and Basra (2000) also reported highest number of fruits in sweets orange due to combined application of micronutrient along with NPK.

For Andhra Pradesh (Anantpur and Pulivedala), Reddy and Swamy (1977) found the manurial schedule of 2.25 to $2.27 \mathrm{~kg} \mathrm{~N}, 1.209 \mathrm{~kg} \mathrm{P}_{2} \mathrm{O}_{5}$ and $0.25-0.37 \mathrm{~kg} \mathrm{~K} \mathrm{~K}_{2} \mathrm{Oper}$ tree as optimum for high yield and better fruit quality of sweet orange. In Rahuri region of Maharashtra, a fertilizer dose of $800 \mathrm{~g} \mathrm{~N}, 100 \mathrm{~g} \mathrm{P}_{2} \mathrm{O}_{5}$ and $400 \mathrm{~g}$ $\mathrm{K}_{2} \mathrm{Oper}$ tree has been advocated for sweet orange cv. Mosambi by Desai et al. (1981).

From the long term (16 years) micro-nutrient trial with mandarian orange cv. Coorg, Shrivastava et al. (1981) reported that plants sprayed with $\mathrm{Cu}, \mathrm{Mn}$, and $\mathrm{Zn}$ gave significantly higher fruit yield than the untreated controlled plant. 


\section{Effect on quality parameter of fruits Fruit girth}

Use of micronutrient specially zinc increased the size, volume, girth of fruits as it regulates the semipermiability of cell wall which mobilized more water into fruits thereby increasing size of fruits in Kagzi lime (Babu et al.,(1982) and Abo-El Krmsan et al.,(2003) found that the best result with regards to yield and fruit quality were obtained due to spraying balady orange trees four times with mixture containing NPK $+\mathrm{Mg}+$ $\mathrm{S} @ 5 \%+\mathrm{Zn}, \mathrm{Fe}, \mathrm{Mn} @ 0.05 \%$ + citric acid @ $1000 \mathrm{mg} \mathrm{kg}^{-1}$. The findings are in agreement with Ingle et al.(2002) in acid lime. Increased in fruit girth observed continuously in two years 2007 \& 2008 (Kazi et al; 2012).

\section{Juice content}

Application of multi micronutrient along with NPK might have improved tree health and this could be the main reason for increase in juice content. It has been reported by various researcher that balanced nutrition considerably increased the juice content in the fruit of healthy trees. The result obtain in this steady confirm the findings of many earlier researcher (Ghosh and Basra, 2000; Kulkarni 2004) in sweet orange. Devi et al. (1997) who found that juice content of sweet orange fruits was significantly increased when the plants were supplied with soil application at $\mathrm{ZnSO}_{4}, \mathrm{FeSO}_{4}$ at $50 \mathrm{~g} /$ tree and combined foliar spray of the micronutrient at $0.5 \%$ concentration.

\section{Total soluble solid (TSS)}

Ghosh and Basra (2000) reported that highest TSS in sweet orange with folier application of $\mathrm{ZnSO}_{4}+$ Borax. Kazi et al. reported that TSS ranged from 9.0 to $10.3{ }^{\circ} \mathrm{Bx}$ showed maximum with NPK + micronutrient.

\section{Ascorbic acid}

Kazi et al, 2012 found that two years experimentation, ascorbic acid was noted to the tune of 46.10 to $58.01 \mathrm{mg} / 100 \mathrm{ml}$ juice and with NPK bulk recommended dose + multi micronutrients. Higher level of sugar due to micronutrient application including boron might be possible. Cause behind increase in ascorbic acid content which is synthesized from sugar (Mengel and Kirkby, 1987).

\section{Reducing and non reducing sugar content-}

Multi micronutrient application resulted in a significant increase in reducing, non reducing multi micronutrients treatments comprised at boron and zinc application along with other micronutrients which have an important role in sugar metabolism.

Dixit et al. (1977) found that increase in sugar content of juice in Kinnow mandarian fruits due to foliar spray of $\mathrm{ZnSO}_{4}+\mathrm{FeSO}_{4}$.

Kulkarni (2004) recorded that, the highest sugar content in juice of sweet orange fruits with the folier application of $\mathrm{ZnSO}_{4}(0.5 \%)+\mathrm{FeSO}_{4}(0.4 \%)+$ Borax $(0.2 \%)$.

Kazi et al (2012) reported that reducing and non reducing sugar maximum with application of NPK bulk recommended dose + multimicronutrient

\section{Acidity}

Kazi et al. (2012) observed that minimum acidity found with application of NPK bulk RDF + multi micronutrient. The acidity decreases in micronutrient applied plant's fruit juice might be due to their utilization in respiration and rapid metabolic transformation of organic acids in to sugars (Brahamachari et al, 1977) Similar result were reported Deolankar and Firke (2001) in banana and by Singh et al.(2003) in pomegranate and Patil and Hiwarale (2004) in acid lime.

\section{Conclusion}

On the basis of all reviews it can be concluded that sweet orange growers of the region should supply multi micronutrient along with recommended dose of fertilizer (RDF) of NPK either through soil \& foliar spray to their sweet orange trees to recover the trees from noticed deficiency in healthy growth of trees and could achieve good yield with excellent fruit quality.

\section{Reference}

[1]. Abo El-Komsan EE, Hegab Amera MY, Fouad A (2003). Response of balady Orange trees to foliar application of some nutrients and citric acid. Egypt. J. Agric. Res., NRC-1(1): 73-90.

[2]. Bose, T. K., Mitra, S.K. and Sadhu, M. K. (1988) Mineral Nutrition of Fruits, Kalyani publication Ed.I p. 66,161.

[3]. Brahmachari VS, Yadav GS, Naresh K (1997). Effect of feeding of calcium, zinc and boron on yield and quality attributes of litchi (Litchi chinensis Sonn.). Orissa J. Hort., 25(1): 49-52.

[4]. Deolankar KP, Firake NN (2001). Effect of water soluble fertilizers on growth and yield of banana. J. Maharashtra agric. Univ., 26(3): 333- 334 
[5]. Desai, U.T., Patil, Y. S., Rane, S. D. and Chaudhari, K.G. (1981) Nat. Symp. Tropical and Subtropical Fruit Crops, Banglore, p.50.

[6]. Devi, D.D., Srinivasan, P. S., Balkrishnan, K. (1997). Influence of $\mathrm{Zn}, \mathrm{Fe}$ and $\mathrm{Mn}$ on photosynthesis and yield of Citrus sinensis. Indian J. Plant. Physiol., 2(2):174-176.

[7]. Dixit, C. K., Yamdagni, R., Jindal, P. C. (1977). A note on the effect of micronutrients spray on quality of kinnow - A mandarin hybrid. Haryana J. Hort. Sci., 6(3-4): 153-154.

[8]. Ghose, S. N. (1990). Nutritional requirement of sweet orange (Citrus sinensis) cv. Mosambi. Haryana J. Hort. Sci. 19: 39-44.

[9]. Ghosh, S. N., Basra, K. C. (2000). Effect of zinc, boron and iron spray on yield and fruit quality of sweet orange Cv. Mosambi grown under rainfed laterite soil. Indian Agriculturist, 44(3/4):147-151.

[10]. Huchche, A. D., M. S. Landaniya, Lallan Ram, R. R. Kohli and A. K. Srivastava. (1998). Effect of nitrogenous fertilizers and farm yard manure on yield, quality, and shelf life of Nagpur Mandarin. Indian J. Hort. 55(2): 108-112.

[11]. Ingle, H. V., Kokate, S. S., Athwale, R. B., Katole, S. R. (2002). Effect of foliar application of zinc and iron on growth, yield and quality of acid lime. Indian J. Citriculture, 1(1): 43-45.

[12]. Kazi, S.S., Ismail, S. and Joshi, K. G.(2012) Effect of multi-micronutrient on yield and quality attributes of the sweet orange. African Journal of Agricultural Research Vol.7(29): 4118-4123.

[13]. Kumar, R., Ahalawat, V. P. and Daulata. B. S. (1993). Growth, yield and quality attributes of Kinnow (C. reticulate) as affected by nitrogen and phosphorus application. Haryana J. Hort. Sci. 22: 8-13.

[14]. Kulkarni, N. H. (2004). Effect of growth regulators and micronutrients on fruit drop, yield and quality in sweet orange (Citrus sinensis Osbeck).Unpublished Ph.D. Thesis, Marathwada Agricultural University, Parbhani, India.

[15]. Mengel, K., Kirkby, E. A. (1987) Principles of Plant nutrition, International Potash Institute, Berns, Switzerland. pp. 453-461.

[16]. Nasreen S., Ahmed, R., Ullah, M. A. and Hoque, M. A. (2013) Effect of N, P, K and Mg application and fruit quality of mandarin, Bangladesh J.Agril. Res. 38(3):425-433.

[17]. Patil, M. N., Hiwarale, J. S. (2004). Growth, yield and quality of acid lime (Citrus aurantifolia Swingle) as influenced by neem cake and fertilizer. PKV Res. J., 28(1): 50-51.

[18]. Ram, L.; R. R. Kohli; A. K. Srivastava; A. D. Huchche and H. C. Das. (1997). Nutritional requirement of Nagpur Mandarin (C. reticulata) grown on vertisol in central region. Indian J. Hort. 54: 91-97.

[19]. Reddy, P.S. and Swamy, G. S.(1977) International Symposium Citriculture, Bsnglore, p.1.

[20]. Srivastava, K. C., Muthappa, D.P., Ganapathy, M.M. and Shamsundaram, K.S.(1981) National Symposium Tropical and Subtropical Fruit Crops, Banglore, p.86.

[21]. Shukla, A. K., A. M. Goswami, S. K. Saxena, R. R. Sharma and Pratap Bhanu. (2000). Effect of nitrogen and phosphorus on growth and yield of Kinnow under high density planting. Ann. Agric. Res. 2: 540-543.

[22]. Singh DB, Sharma BD, Bhargava R (2003). Effect of boron and GA3 to control fruit cracking in pomegranate (Punica granatum). Curr. Agric., 27(1-2): 125-127.

[23]. Tariq M, Sharif M, Shah Z, Khan R (2007) Effect of foliar application of micronutrients on the yield and quality of sweet orange (Citrus sinesis L.). Pakistan J. Biol. Sci., 10(11): 1823-1828. 